\title{
Testicular Polyembryoma
}

National Cancer Institute

\section{Source}

National Cancer Institute. Testicular Polyembryoma. NCI Thesaurus. Code C40962.

A rare malignant germ cell tumor that arises from the testis and is characterized by the presence of embryoid bodies. 